Laboratorio de Arte, 7-1994 http://dx.doi.org/10.12795/LA.1994.i07.04

\title{
LA NOBLEZA SEVILLANA SUS LUCHAS Y SU ARQUITECTURA
}

\author{
POR ENRIQUe Morales MÉNDEZ
}

\begin{abstract}
El modelo de la nobleza sevillana, de tradición urbana, nada tiene que ver con el que se daba en Castilla o regiones norteñas, de vida encerrada en castillos elevados e inaccesibles. La nobleza de estas latitudes convive en las ciudades y así barrios y plazas recuerdan no sólo a órdenes religiosas, sino a sus nobles moradores. Por ello, junto a la torre de las iglesias siempre estuvieron presentes las torres y torreones civiles, como símbolos de poder más que por razón defensiva.

La nobleza siempre fue querida y respetada en nuestra ciudad pues los escasos privilegios económicos por ella logrados, nunca representaron carga para el pueblo, de aquí que los enfrentamientos se dieran dentro de la misma nobleza, no entre hidalgos y plebeyos. Muerto Enrique II en 1379 se inicia el período denominado de los "Bandos de Sevilla", luchas entre familias de linaje por el gobiemo de la ciudad, satisfacer rencores o por orgullo. Notables familias como las de Ponce de León o los Guzmanes de Niebla junto con sus criados, se encastillaban en sus casas y en las torres de las iglesias, corvirtiendo sus moradas en verdaderas fortalezas. Habría que esperar la llegada de los Reyes Católicos para que la situación fuera controlada y los nobles sometidos, aunque con ello la torre de linaje perdiera su vigencia.
\end{abstract}

Nobility was always wanted and respected in our city since the scarce economic priviledges achieved by its members never implied a burden for the people, and therefore, there were always confrontations inside nobility itself and never between noblemen and plebeians. Once dead Henry II in 1379, the socalled period of "The Bands of Seville" begins; fights between noble families in order to conquer the power of the city, to take revenge, or due to pride. The domains of Ponce de León, the Guzmanes from Niebla and other outstanding families, together with their servants, locked themselves in their houses and church towers turning their dwellings into real fortresses. Time had to pass until the Catholic Monarchs arrived so that the situation was under control and noblemen were submitted, although in this way, the social piramid lost its effect.

\section{1.- GENERALIDADES}

Es vital la importancia del estudio pormenorizado del medio social en el cual se desarrolla la arquitectura y ello es fácil de entender si se tiene en cuenta que es, esta bella arte, la envolvente física de las propias exigencias que definen al citado medio o entorno social.

Estas exigencias constituyen el conjunto de apetencias o demandas que plantea dicha sociedad y puede decirse que cada época produce lo que aprecia 
como necesario. Las tipologías, al igual que los sistemas constructivos, cambiaron o perduraron en función de la estabilidad social y la permanencia de las razones que las originaron!.

El clima junto con otros factores físicos, pueden tomarse como relativamente invariables y originan constantes que definen a la arquitectura propia de un lugar; no obstante, los cambios de modo de vida alteran las costumbres y con ellas, aquellas constantes históricas que le dieron singularidad. Esto se manifiesta claramente en la arquitectura doméstica y llevó a Lampérez ${ }^{2}$ a considerar que:

La arquitectura privada ofrece la extraña dualidad de ser variable socialmente a la vez que permanente geográficamente.

Las torres y torreones, como razón defensiva, matizados en su forma y uso por constantes locales, tomaron en cierto momento histórico, el carácter de símbolos de poder, siendo esta característica el punto en común de la clase social a la cual servían. Se convierten, en palabras de Alejandro Collantes de Terán, en lo oficial, lo sesudo, lo autoritario ${ }^{3}$. En la ciudad italiana de San Gimignano, se prohibía construir torreones a los vecinos que no eran nobles de condición ${ }^{4}$.

Un detenido análisis de la evolución de la sociedad sevillana, en cuyo seno se aprecia un poderío disperso en su distribución, nos descubre las apetencias y motivaciones a lo largo de la historia de esta nobleza feudal, que ha quedado simbolizada en la coronación torreada de sus edificios, con remates que se hermanan a la cúpula renacentista, fiel reflejo de un léxico monárquico ${ }^{5}$.

No pudo ser el torreón, en razón alguna, un aprovechamiento de un lugar innecesario de difícil acceso, en donde no existía la especulación del espacio. Ese erigirse en el cielo azul, buscaba junto a una expresión más gráfica, remarcar simbólicamente el asentamiento de un soporte dinástico.

\section{2.- LA NOBLEZA EN LA SOCIEDAD ESPAÑOLA}

Aunque los grandes títulos tienen sus raíces en la Reconquista y a resultas de hechos de guerras, con posterioridad se otorgaron y crearon por otros motivos, dando con ello continuidad y variedad a una larga jerarquía nobiliaria.

En Castilla, entre 1312 y 1350 y durante el reinado de Alfonso XI, los títulos de conde y duque no eran exclusivamente de oficio, palacio, gobierno e incluso de la milicia. Se crearon los condados de: Trastamara, Lemos, Albuquerque y Aguilar, creyéndose que el primer Marquesado de Castilla fue el de Villena. Este

1. Vicente Lampérez y Romea. Arquitectura Civil Española de los siglos I al XVIII. Tomo I. Arquitectura Privada. Pág. 14.

2. Vicente Lampérez y Romea. Opus cit. Pág. 31.

3. José Antonio Calderón Quijano. Las Espadañas de Sevilla. Pág. 19.

4. Diccionario Universal Espasa. Tomo LXII. Pág. 1263.

5. Alberto Villar Movellán. Introducción a la arquitectura regionalista. El Modelo Sevillano. Pág. 33. 
título sería concedido por Enrique IV "El Impotente", en el tercer cuarto del siglo XV a Juan Pacheco, después Duque de Escalona, persona muy vinculada a la ciudad de Sevilla ${ }^{6}$, de quién aseguraría el Cardenal Mendoza que era de estirpe judío conversa.

Mientras en Castilla los títulos eran personales, en Aragón lo fueron reales, basados en feudos o territorios, tomando el poderío político de la nobleza una alta cota como lo demuestra el juramento que prestaban los nobles en Aragón: "Nos, que valemos tanto como vos y que juntos más que vos, os facemos rey". Con el tiempo esta forma de poder se tornó en preponderancia por una supremacía económica.

También proliferaron estos otorgamientos durante el reinado de Felipe V y en la Restauración, aunque las nuevas concesiones ya no respondían a las hazañas guerreras y sí a la diplomacia o burocracia palatina, hasta el punto de que con el tiempo y ya en el siglo XIX se otorgaron a políticos, generales, parlamentarios y a hombres de ciencia y de las artes.

La "Grandeza de España" recaería desde un principio en los títulos pertenecientes a las veinte casas más poderosas, que eran a su vez las de más alta nobleza. Entre éstas, cabe destacar las de Alba de Tormes, del Infantado, de Medina Sidonia, de Medinaceli, de Osuna, de Arcos, de Lemos, de Villena, etc.

Títulos como el de barón y vizconde, traspasada la barrera feudal, fueron extraños en Castilla, no así en Aragón y Cataluña en donde el feudalismo se asent 6 con mayores raíces.

Andalucía nunca tuvo una hidalguía numerosa, aunque se dieron extraños casos de nobleza media o baja ${ }^{7}$. Prosperaron eminentes títulos de la alta nobleza, con importantes fortunas nobiliarias que se fueron acumulando durante siglos, con grandes riquezas y fuertes privilegios ${ }^{8}$ que sirvieron para ampliar sus latifundios.

Los títulos de nobleza fueron abolidos en dos ocasiones; en 1873 por Nicolás Salmerón y posteriormente el 14 de Abril de 1931 con la Segunda República, aunque anteriormente las Cortes de Cádiz habían dejado en suspenso los señoríos jurisdiccionales y los privilegios señoriales, asimilando a los señoríos territoriales la propiedad privada. Este hecho motivó que se identificara a la nobleza con el latifundismo.

En la historia reciente, es decir, tras la guerra civil española, no sólo se restablece y mantiene todo el uso latifundista sino que se conserva toda la legislación de antes de la República, recobrando vigor los títulos carlistas y otros concedidos por los Reyes de España en territorios que pertenecieron a la Corona. Con la actual monarquía, un decreto del Gobierno Socialista de 23 de Mayo de 1984, recortaría los privilegios de los "Grandes de España".

6. Antonio Collantes de Terán. Sevilla en la Baja Edad Media. Pág. 224.

7. Antonio Domínguez Ortiz. Orto y Ocaso de Sevilla. Pág. 84.

8. Francisco Aguilar Piñal. La Sevilla de Olavide. Pág. 58. 


\section{3.- LA NOBLEZA EN LA SOCIEDAD SEVILLANA, DE LA SEVILLA VISIGODA A LA SEVILLA ARABE.}

Los pueblos bárbaros conservaron en nuestras tierras una organización basada en un mandato provincial desempeñado por el "duque", mientras que en un escalón de orden local, el "comes", ocupaba la representación ciudadana.

En el amplio período árabe, se pone de manifiesto la carencia de un control por el poder y surgen desde muy pronto las luchas de banderías entre familias de la nobleza. Esta falta de apoyo a la justicia por parte de la clase alta sevillana, lleva a Miramolín, que llega a Sevilla derrotado de las Navas de Tolosa, a establecer fuertes medidas de represión.

Las continuas luchas, en esta etapa, entre las familias y partidos dinásticos, hacen que a la muerte de Aben Huz, lo cual ocurrió sin previsión de sucesión, se buscara una nueva fórmula similar en su esquema al de las ciudades estados griegas o a las italianas del renacimiento, a pesar de encontrarnos aún en el primer tercio del siglo XIII.

\section{4.- SEVILLA Y LOS PRIMEROS REYES CRISTIANOS}

Tras la Reconquista de nuestra ciudad, la nobleza sevillana desaparece por completo, surgiendo una sociedad importada de Castilla e incluso de muy variados puntos de Europa. De los doscientos hidalgos documentados, sobre una población de quince mil habitantes, sólo diez familias serían de linajes de abolengo en los siglos XV y XVI.

Se caracteriza esta etapa de la Reconquista por ser un gran campo de acción para la lucha, pues las amplias fronteras a defender, que iban desde Portugal a Granada, quedaban muy desguarnecidas. No extraña pues que en tales circunstancias, acudieran a secundar al Rey Santo en su lucha contra el infiel, individuos de todos los ámbitos imaginables. Asturianos, vizcaínos, leoneses, palentinos, burgaleses, navarros, gallegos y catalanes, entre otros, acudieron a nuestra expectante comarca.

Tampoco faltaron extranjeros que llegaron en gran número de: Génova, Pisa, Venecia y Lombardía. Todos ellos serían los antecesores de los actuales pobladores andaluces, pues según Gonzalo Martínez Díaz:

Ni un solo moro quedó en estas tierras tras las Reconquista ${ }^{9}$.

Ellos trajeron sus costumbres, ya que nada les impedía seguir manteniendo sus formas de vida e importaron hasta la imagen de sus edificios. No encontraron

9. Gonzalo Martínez Díaz. Leyes de Alfonso X. I Volumen. Fundación Claudio Sánchez Albornoz; también lo recoge $\mathrm{ABC}$ en pág. 65, de su número 30/6/85. 
en este campo impedimento alguno en su producción y desarrollo, ya que en el último período árabe las casas debieron ser de paramentos lisos, sin adornos ni ostentación y con la mínima expresión hacia el espacio exterior, para así no desvelar la condición de sus moradores ${ }^{10}$. Hay que pensar que en la etapa almohade el miedo a la fiscalía del lujo, les llevó incluso a ocultar muchas de las ricas yeserías que decoraban los edificios.

De esta forma, era posible el nacimiento de nuevos estilos incorporados a nuestra ciudad por los nuevos moradores. Entre ellos, alcanzó gran importancia y desarrollo la colonia genovesa que llegó incluso a nominar calles, estableciendo su área principal de asentamiento entre la plaza de San Francisco y la carrera de Alemanes. Personaje destacado dentro de esta comunidad fue el poderoso Micer Niculoso, conocido como Nicolás de la Torre del Oro, por haberle sido confiada la custodia de la misma ".

De igual modo debió ocurrir con la comunidad lombarda, que ejerció usura en nuestra ciudad y a la cual se debe la nominación de Placentines, en recuerdo a la Plasencia de Lombardía.

LLegó a tal punto la presencia de extranjeros, que a principios del siglo XVIII había de ellos quince mil avecindados en nuestra ciudad, principalmente flamencos ${ }^{12}$.

Los títulos nobiliarios en esta etapa de la vida sevillana, surgen de hazañas y hechos de guerra, con nominaciones diversas en su rango y diferente carácter de los que eran otorgados en otras regiones españolas. Estos nuevos títulos alternaron con los que se habían conservado desde el siglo XIII y han permanecido hasta la actualidad, como es el caso del Marquesado de Paredes que se remonta a 1272. Otros, como el de Valencina, provienen de aquellas familias que acompañaron a Fernando III El Santo en la conquista de nuestra ciudad.

El modelo de la nobleza sevillana, de tradición urbana, nada tenía que ver con el que se daba en Castilla o regiones norteñas, caracterizado por su aislamiento y forma de vida encerrada en castillos elevados e inaccesibles. La nobleza de estas latitudes convive en las ciudades y, de esta forma, barrios, calles y plazas recuerdan no sólo a órdenes religiosas o monasterios, sino a sus nobles moradores.

San Julián cobijó al Obispo de Cartagena, a los hidalgos Ximén López de Gamarra, García Fernández de Tomisedo y Ferrán Ruiz de Matrera. En San Marcos habitaron los Melgarejos junto con Alfonso Pérez de Toledo, Día Fernández de Villasilos y Gonzalo Martínez de Quintanilla. En Santiago lo hicieron Meléndez Forniellos y los caballeros Domingo Gutiérrez de Solorzano, Alfonso García de Madrid, Gonzalo Ruiz de Burvoses y García López de Medina ${ }^{13}$.

10. Leopoldo Torres Balbás. Ciudades Hispano Musulmanas. Tomo I. Historia e Instituciones. Organización de las ciudades y calles. Pág. 395.

11. Antonio Ballesteros Beretta. Sevilla en el siglo XIII. Págs. 44 y 49.

12. Francisco Aguilar Piñal. Opus cit. Págs. 62 y 63.

13. Antonio Ballesteros Beretta. Opus cit. Págs. 31 y 32 . 
Eran queridos y respetados pues los escasos privilegios económicos de la nobleza sevillana, nunca representó carga para el pueblo. Sus principales ingresos provenían de la administración y explotación de sus extensos territorios rurales y del propio comercio ${ }^{14}$.

De aquí que los enfrentamientos nunca partieran como lucha entre hidalgos y plebeyos, sino de los señores de la nobleza entre sí. Un ejemplo claro de esta amigable situación fue el "Motín de la Feria", de 1652. En él, la nobleza no sólo fue respetada, sino que fue requerida para que interviniera y restableciera, con su consejo y dirección, el orden en el conflicto.

La nobleza era depositaria del prestigio de la sociedad sevillana. LLegó a adquirir gran opulencia y riqueza, la cual se manifestaba en las crónicas de legendarios caballeros, como es el caso de Quiroz, quien residía en la plaza de la Gavidia, campeando sobre su puerta la famosa inscripción "Nihil dificit est" y en su escudo de armas el dicho popular de "Después de Dios, la casa de Quiroz". De esta casa, cuenta la leyenda, que tras sufrir un incendio que consumió hasta los cimientos, era tal su riqueza en plata labrada, que ésta corría derretida entre los escombros.

\section{5.- LA ORIGINARIA NOBLEZA SEVILLANA.}

En el escalón superior de la vieja nobleza con residencia habitual en nuestra ciudad, destacaron dos casas, la de Guzmán y la de Ponce de León, ambas "Grandes de España" desde $1520{ }^{15}$. El apellido Ponce de León procedía de la unión de Don Pedro de Minerva y Doña Aldonsa de León, hermana natural del Rey Femando III. Aunque Don Pedro de Minerva arrancó Marchena de las manos de los árabes, esta familia no conseguiría el Señorío de Marchena hasta el año 1309, en tiempos de Fernando IV ${ }^{16}$. También intervendría en múltiples acciones de guerras, que ya en pleno siglo XV le llevarían al Marquesado de Cádiz y al Condado de Arcos, posteriormente convertido en Ducado.

Don Alfonso Pérez de Guzmán era de Sevilla. De origen bastardo, intentó oscurecer su nacimiento con hazañas guerreras como la defensa de Tarifa en tiempos de Sancho IV, por cuyo motivo incorporó a su nombre el calificativo de "El Bueno". Casado con Doña María Alonso Coronel, pasó a integrar gloriosas páginas de la historia sevillana.

$\mathrm{Al}$ autorizar el Rey Don Sancho el levantamiento de castillos, con el fin de dotar de mayor defensa el vasto territorio que quedó bajo su gobierno y fortalecer de este modo las fronteras que definían las tierras conquistadas, se erigieron magníficas fortalezas.

14. Antonio Domínguez Ortiz. Opus cit. Págs. 84 y 85.

15. Antonio Collantes de Terán. Opus cit. Pág. 224.

16. Emilio Serrano Díaz. Castillos de Andalucía. Tomo II. Pág. 78. 
Entre ellas destacan las de Fregenal, Aroche, Villanueva del Camino, hoy del Río, Santa Olaya y Lebrija. El poder que adquirieron estos feudos junto a la falta de gobierno real, dio origen a que la nobleza, de nuevo, se enzarzara en revueltas y luchas de banderías, en el período comprendido entre 1284 y 1474, año de la muerte de Enrique IV ${ }^{17}$. Estas luchas no cesarían hasta que la realeza decidió tomar parte, e impuso su poderío y respeto ya en 1521 bajo el reinado de los Reyes Católicos.

Otro hecho de gran importancia para la nobleza sevillana se produce durante el reinado de Fernando IV, sucesor de Sancho IV, con el casamiento de las dos hijas de Don Alonso Pérez de Guzmán.

La mayor, Doña Isabel, lo hizo con Fernán Pérez Ponce de León, Señor de Marchena, aportando ella la villa de Rota que quedó unida a la casa de los Marqueses de Cádiz y de los Duques de Arcos, de gran rivalidad con la rama masculina de los Guzmanes, Señores de Sanlúcar. Con el tiempo, esta casa de Guzmanes se convertiría en originaria de la de mayor prestigio, riqueza y poderío, tras conseguir el Condado de Niebla y el preciado Ducado de Medina Sidonia con Juan de Guzmán como primer duque en el siglo XV. LLegaron a poseer ochenta y tres mil vasallos distribuídos en un total de una treintena de poblaciones, algunas tan importantes como Vejer, Chiclana, Niebla, Trigueros, Huelva y la propia capital del Ducado.

Leonor, la segunda hija, llevando como dote la villa del Puerto de Santa María, contrajo matrimonio con Don Luis de la Cerda, más tarde Príncipe de las Fortunadas y de esta unión procede la Casa de Medinaceli ${ }^{18}$. De rancio abolengo, estaría unida desde su origen a Sevilla, en donde fijó su residencia, permaneciendo hasta la segunda mitad del siglo XV en que se desvinculó de nuestra ciudad ${ }^{19}$. Al Ducado de Medinaceli pertenecían como asentamientos principales: Alcalá de los Gazules, Bornos, Chucena y El Coronil.

A la muerte de Fernando IV (1311), Alfonso XI con dos meses de edad, era proclamado rey, bajo la tutela de su abuela Doña María de Molina, su reinado estaría marcado por ser época de grandes luchas, no sólo por las ambiciones de los infantes, sino por disputas entre la nobleza.

De los amores de Alfonso XI, casado con Doña María de Portugal, con Doña Leonor de Guzmán, "la más apuesta mujer que había en el reino", tuvo varios hijos, entre ellos Don Enrique de Trastamara y Don Fadrique. De esta forma, se convertía la familia de los Guzmanes en la más poderosa de la corte, pues Doña Leonor era de hecho la verdadera reina de Castilla ${ }^{20}$.

Al morir el rey Don Alfonso, en 1350, el rey legítimo Don Pedro I, tendrá que enfrentarse a sus hermanos bastardos que usarán de sus privilegios feudales para combatir el poder central.

17. Joaquín Hazañas y La Rua. Historia de Sevilla. Págs. 123 a 140.

18. Joaquín Hazañas y La Rua. Opus cit. Págs. 127 y 128.

19. Antonio Collantes de Terán. Opus cit. Pág. 224.

20. José $\mathbf{M}^{\mathbf{a}}$ de Mena. Historia de Sevilla. Pág. 99. 
En esta época, prelados y nobles eran en sus señoríos pequeños reyes. Disponían de ejército, cobraban impuestos, levantaban horcas y picotas, administraban justicia, incluso en causa criminal, y sin conocimiento del rey aplicaban la pena de muerte. Tan gran autonomía e independencia, puesta de manifiesto en esta soberanía, parecía obligada y se admitía por la preocupación de defender las fronteras.

Esta situación junto con la carencia de botines y tributos que en otros tiempos se obtenían de los reyes moros, forzaría al monarca a tomar medidas políticas que molestarían a la nobleza y a los ciudadanos. A estos tiempos se remonta el "Somatén Ciudadano", paso previo a lo que ya en tiempo de los Reyes Católicos se denominaría la "Santa Hermandad". A pesar del esfuerzo, no se conseguiría acabar con el bandidaje y el gran número de partidas armadas que actuaban protegidas por la nobleza.

Tras el fraticidio de Montiel en 1369 accede al poder Enrique II, nacido en Sevilla y con él, la Casa de Trastamara favorece a nuestra ciudad y sobre todo al Señor de Sanlúcar, Don Juan Alonso de Guzmán, a quien casó con su sobrina Doña Juana, hija del difunto Don Fadrique y más tarde, habiendo enviudado de aquella, con su hija ilegítima Doña Beatriz, obteniendo amplio señorío con el título de Conde de Niebla ${ }^{21}$.

Muerto Enrique II en 1379, le sucede Juan I, iniciándose el período denominado de los "Bandos de Sevilla". En esta etapa de luchas, los señoríos de Ponce de León, los Guzmanes de Niebla y otras notables familias, junto con sus criados, se encantillan en sus casas e iglesias, levantan torres defensivas y convierten sus moradas en verdaderas fortalezas.

La disputa por el gobierno de la ciudad les llevaba a armarse y a agrupar a parientes y amigos, criados y partidarios de cada estirpe familiar, asalariando incluso a gentes de guerra. Ensangrentaron la ciudad con múltiples batallas callejeras que, en algunos casos, respondían al simple hecho de satisfacer rencores o por orgullo ${ }^{22}$.

Si bién cuando era preciso, la nobleza unida ofrecía al rey o a la patria, la más pura lealtad, el más ligero roce convertía la ciudad en campo de batalla y de destruccion:

... Pues no había gobierno, ni orden, ni se conocía más ley que la de la fuerza ${ }^{23}$.

Tal relajación de autoridad originó en los albores del reinado de Enrique III, el 6 de junio de 1391, el asalto de la Gran Aljama y la conocida matanza de judíos. Las luchas callejeras eran cada vez más encarnizadas ahora entre el Conde

21. Joaquín Hazaña y La Rua. Opus cit. Págs. 133 y 134.

22. José $\mathbf{M}^{2}$ de Mena. Opus cit. Pág. 111.

23. Félix González de León. Noticias Históricas del origen de los nombres de las calles de esta Muy Noble, Muy Leal y Muy Historica Ciudad de Sevilla. Págs. 50 y 51. 
de Niebla, tutor de Enrique III, y sus irreconciliables enemigos, el almirante Alvar Pérez de Guzmán y el Señor de Marchena, Ponce de León; se alternaron en la ocupación de la ciudad y en el desalojo de ella de sus contrarios. La situación llegó a tal punto que el mismo monarca, tras cerrar la cerca, tuvo que intervenir condenando a muerte al Conde de Niebla y a Don Pedro Ponce de León, pena que conmutaría al arrojarlos fuera de la ciudad en 1403.

Tras el saqueo de la judería, Enrique III concedía a su Justicia Mayor, Diego López de Estúñiga, parte de este barrio, donde estableció su residencia y su linaje. Este, el de los Estúñiga, es el más antiguo de la nobleza nueva y añadiría con el tiempo los títulos de Conde de Ledesma y Duque de Béjar ${ }^{24}$.

Otra de las familias establecidas en nuestra ciudad en este período, precisamente en 1390, es la de los Farfanes, tras la vuelta a la península de su vasallaje con el Rey de Marruecos. Descendientes de godos, poseyeron capilla propia en la iglesia de San Martín ${ }^{25}$.

Tras la muerte de Enrique III, en 1406, el reinado de Juan II no encuentra apoyo ni para crear la gran Castilla, ni para acabar con las revueltas sevillanas. Esta vez, los bandos los capitaneaban los alcaldes mayores, Don Pedro de Zúñiga y Don Alonso Pérez de Guzmán, Señor de Ayamonte, reforzados por el Conde de Niebla, quién acompañó al primero, mientras el Señor de Marchena lo hacía con el segundo. Los desórdenes llegaron a tal punto que el infante Don Enrique quiso alzarse en toda Andalucía y apoderarse de Sevilla, lo que fue impedido por el Conde de Niebla que recibió en recompensa el título de Duque de Medina Sidonia. A este período de mediados de siglo, se remonta el título de Conde de Molares a Per Afán de Rivera ${ }^{26}$.

Durante el reinado de Enrique IV, sucesor de Don Juan II, la situación se agrava, llegándose en 1463, a que la lucha de nobles divida tanto la ciudad como la comarca. Félix González de León, nos lo refiere de la forma siguiente:

Los particulares pretendian encantillarse en sus casas a cuyo fin, fabricaban torres fuertes que guarnecian de armas y ponian de forma defensiva y ofensiva, de que había muchas que luegon destruyeron los Reyes Católicos, de cuyo derribo sólo se libertó una de la que hablaré, en la calle del Canco y hasta los templos los hicieron propugnáculos de bandos y armas, ocupándolos a título de guardarlos y ganando para ellos previsiones reales. Lo cual fue más frecuente en las parroquias, las cuales tomó a su cargo, cada una, un linaje ${ }^{27}$.

24. Antonio Collantes de Terán. Opus cit. Pág. 224.

25. José $\mathrm{M}^{\circledR}$ de Mena. Opus cit. Pág. 113.

26. Antonio Collantes de Terán. Opus cit. Pág. 224

27. Félix González de León. Opus cit. Noticias Históricas del origen de los nombres de las calles ... Pág. 96. 
De esta forma, la nobleza, por privilegio real, pudo usar de las parroquias no ya para capellanías, patronazgos o entierros, sino para hacerse fuertes $y$ defenderse, causando a veces graves daños a sus edificaciones, como en los casos de San Marcos y del Salvador. Las torres de las iglesias se convierten en fortalezas de las que no podemos excluir la Giralda, ni la Torre del Aceite que, situada entre la Catedral y el antiguo Colegio de San Miguel, fue campanario de la Iglesia Mayor cuando la Giralda aún no disponía de campanas.

Cada noble se hacía fuerte, cuando lo precisaba, en la torre de la iglesia más cercana ya que existía cierta dependencia entre las iglesias y las familias nobiliarias. Este hecho perduraría a lo largo de la historia y así: los Guzmanes de Medina y Duques de Medina Sidonia lo harían en San Miguel, los Manueles en San Isidoro, los Cerones en la Magdalena, los Ribera en Sta. Marina, los Torres en San Julián, los Santillanes en San Gil, los Coroneles en San Vicente, los Ponce de León en Santa Catalina, los Esquibeles en San Pedro, los Saavedras de los Mariscales en San Juan de la Palma, los Saavedras del Viso en San Martín, los Cervantes en Omnium Sanctorum, los Mendoza en San Vicente, los Villafrancas en el Sagrario, los Prados en Sta. Lucía, los Melgarejos en San Nicolás, los Padillas en San Marcos, los Coronados en San Andrés, los Jaenes en San Lorenzo, los Guzmanes de Orgaz en San Estebán, los Tenorios en Santiago, los Cárdenas en San Román, los Maldonados en San Ildefonso,etc. ${ }^{28}$.

Las luchas entre familias serían muy encarnizadas como nos cuenta Ortiz de Zúñiga, refiriéndose a la refriega ocurrida entre el 21 y 25 de julio de 1470 , a cargo del Conde de Arcos, que en los últimos años del reinado de Enrique IV, se había convertido en Marqués de Cádiz.

Las huestes del Marqués de Cádiz, pusieron fuego a la iglesia de San Marcos y se quemó todo cuanto era de madera. El Duque tenía de su lado a la mayor parte de Sevilla y con ella, el Adelantado de Andalucía, D. Pedro Enríquez y fue entonces cuando el Marqués se hubo de retirar a las collaciones de Sta. Catalina y San Román, donde estuvo fortificado.

La reconstrucción de San Marcos en 1478, debió ser motivada con ocasión de este incendio ya que su torre es, constructiva y estéticamente, de gran parecido con la Giralda, por lo que puede pensarse que ambas se realizaran por las mismas fechas ${ }^{29}$. Hasta 1936, según parece, quedaron en ella piezas heráldicas de Enríquez y Guzmanes ${ }^{30}$.

28. Memorias Antiguas Sevillanas (Biblioteca Capitular). Pág. 143. Joaquín Hazañas y La Rua. Opus cit. Pág. 140.

29. Félix González de León. Noticias Artísticas Históricas y Curiosas de todos los edificios públicos, sagrados y profanos de esta Muy Noble Ciudad de Sevilla y de muchas casas particulares. Tomo I y II. Pág. 103.

30. J. González Moreno. "Rincones Sevillanos". En el diario ABC, 2 de septiembre de 1.984. 
No era la torre patrimonio exclusivo de las iglesias, ya por estas fechas en el perfil de la ciudad se acusaba la presencia de gran número de torreones, teniéndose constancia de algunos de ellos y de las casas a que pertenecían. Este es el caso de la de los Villafrancas, que más tarde fue la de los Marteles y de éstos pasó a los Saavedras; según Félix González de León, era de las únicas de esta tipología que aún existían en su época. Muchas de estas torres construidas en Sevilla por los años 1450, motivadas por las enemistades de las casas de Niebla y Marchena, entre cabildos eclesiásticos y seculares, entre partidarios del Rey de Navarra y el Infante Don Enrique y entre las casas de Arcos y Medina Sidonia, fueron destruidas por los Reyes Católicos.

Esta de los Villafrancas se remontaba a 1451, según aparecía rotulado en el interior de la bóveda con el siguiente texto:

REINANDO EN LOS REINOS DE CASTILLA
NUESTRO SEÑOR EL REY D. JUAN,
MANDARON FACER ESTA TORRE EL HONR
RADO CABALLERO FRANCISCO DE VILLA
FRANCA E LA HONRRADA CONSTANZA
FERNANDEZ SU DUEÑA. EL AÑO DEL
NACIMIENTO DE NUESTRO SALVADOR
JESUCRISTO DE 1451.

Fue derribada en 1811 , por los franceses para hacer la plaza de la Encarnación ${ }^{31}$. Tras esta demolición, aún quedaba en pie aunque muy alterado, uno de los altos y fortísimos torreones de la Casa Ducal de los Medina Sidonia ${ }^{32}$, de la que se cuenta que tanto impresionó a Felipe II en su entrada triunfal, que preguntó si era la casa del Señor del lugar.

En realidad, era un magnífico edificio al que a fines de 1500 , se le dio perspectiva con el derribo de varias casas de la misma propiedad. Su gran portada estaba flanqueada por dos medias columnas dóricas, sobre cuya cornisa se abría el balcón. La fachada se completaba con ventanas en el primer cuerpo y balcones en el segundo. En cada extremo debió tener torreones altos y diáfanos con arcos sobre columnas y barandas de hierro. Según González de León ${ }^{33}$, hacia 1839 ya faltaba totalmente el de la esquina de Armas y un pedazo del otro. Tras estas demoliciones y con la salvedad de la Torre de Don Fadrique, ningún resto ha quedado de esta arquitectura torreada originaria que no sea referencia documental.

31. Félix González de León. Opus cit. Noticias Históricas del origen de los nombres de las calles... Págs. 252 y 253.

32. Joaquín Hazañas y La Rua. Opus cit. Pág. 140.

33. Félix González de León. Opus cit. Noticias Históricas del origen de los nombres de las calles... Págs. 49 y 50. 


\section{6.- EL VASALLAJE DE LA NOBLEZA A LOS REYES CATOLICOS.}

Volviendo de nuevo al discurrir de la historia, el 11 de diciembre de 1474 fallece Enrique IV y, con su muerte, nos llega la mano dura de los Reyes Católicos que reprimen sin consideración estos desmanes. Concretamente, ese mismo año, la inseguridad ciudadana llega a tal punto que, tras la conquista de Gibraltar, hortelanos y labradores del Aljarafe no se atreven a entrar en la ciudad, por lo que el hambre y la carestía de precios se adueñan de ella ${ }^{34}$.

La sabiduría de la Reina, más que la espada de Fernando, hace renacer la paz en la nobleza sevillana y pronto domina el deseo de servicio a la patria, como queda de manifiesto en la Guerra de Granada. En palabras de Zúñiga en sus Anales:

Parece que la justicia volvió a descender del cielo a la tierra, principalmente en esta ciudad.

Pero no por ello carece este momento de incidentes. A la venida de la Reina, el 25 de julio de 1477, no acude el Marqués de Cádiz a Sevilla a prestar obediencia y, aunque el de Medina Sidonia sí lo hace, se niega a entregar alcázares y castillos hasta que su rival no lo haga por su parte. La entereza de la Reina logra que, a la llegada de Fernando el 13 de septiembre, ambos señores reconcialiados, compitan en agasajos.

Poco a poco, tras someter las cabezas más visibles, los reacios van cayendo al vasallaje uno a uno. Así ocurrió en los casos de los señores de Castellar y del Viso o del mariscal Fernandarias de Saavedra, quien fue derrotado por Rodrigo Ponce de León. Controlada la situación, era preciso no consentir nuevas alteraciones ni admitir elevaciones en las fortalezas que pudieran dar pie a nuevas luchas.

Gracias a los Reyes Católicos la nobleza había caido y la torre, como símbolo de poder o de lucha, había perdido su vigencia.

La prohibición de torreones no fue exclusiva para la construcción de fortalezas por parte del infiel, ni para la nobleza de nuestra ciudad. Tenemos noticias referenciadas a la ciudad de Cáceres de aplicación de la Cédula dada el 12 de mayo de 1476 en Madrigal, ordenando la inmediata demolición de todas las torres, en el término de treinta días, de las casas de los caballeros y escuderos ${ }^{35}$ :

"Por manera que queden yguales con las otras casas donde estan fechas e edificadas e todos biuan e estén seguros", pues les habían hecho "relación

34. José $\mathrm{M}^{\mathrm{a}}$ de Mena. Opus cit. Pág. 116.

35. Leopoldo Torres Balbás. Crónica de la España Musulmana. Al Andalus. Tomo IV. "Cáceres y su Cerca Almohade". Pág. 138 y 139. Recoge notas del Archivo de la casa de Lopez Montenegro. Colec. de docs., 1" sign. prov., números 1-6, ap. IV, según cita Floriano en "La Villa de Cáceres y la Reina Católica I", reproduce el documento en las Págs. 106-111. 
que en esa villa, en muchos tiempos acá, por cabsa de algunas torres que están en algunas cassas principales de dicha villa, se han fecho o han acaecido grandes escandalos, e mouimientos, e ruidos e feridas, e muertes de omes; porque son defendidas las dichas casas con el esfuerzo e fauor de los caualleros e otras personas que tienen las dichas casas e torres, de lo qual se han recrecido e recresce a los vesynos e moradores de la dicha villa e su tierra grandes daños".

En dicha ciudad, incluso se dictan órdenes para acabar con los desórdenes de la nobleza, concediendo permisos para construir, pero prohibiendo previo juramento:

...No levantar en el dicho suelo, torre ni casa fuerte, ni faga alderredor de la dicha casa ni barrera ni baluarte, ni otra fuerça, nin defensa alguna; nin faga la dicha casa más alta que quanto fuere el altura de los otros de las otras moradas; quende ficiere, en tal manera que, juntos los tejados de la dicha casa con las paredes dellas sin que aya ningún apartamiento, ni división de lo uno a lo otro, ni menos pretil, ni almenas y que no pueda facer ni faga saeteras ni troneras algunas ${ }^{36}$.

En la disposición cacereña de 9 de julio de 1477 la reina dicta que todos los que tuvieran torres en las casas de la villa y de los arrabales, las entregasen libremente al justicia o corregidor cuando éste las pidiese y que si desde esas torres pelearan o tirasen piedras, saetas o tiros de pólvora, la justicia las derribase de por su pie. Ordena así mismo, que las arqueras hechas en las citadas torres fuesen derribadas en el término de ocho días, a requerimiento del corregidor, cerrando troneras y saeteras y cubriendo y tejando las torres, sin dejar en ellas almenas ni andamio alguno.

Por existir, seguramente, varias torres iniciadas, se especifica también que tan sólo puedan levantarlas hasta la altura de los tejados de las casas y que sus paredes no fueran más gruesas que las restantes de éstas ${ }^{37}$.

Disposiciones posteriores insistirán en estas prohibiciones a los particulares $y$, taxativamente, se recordará en reiteradas ocasiones y en distintas provincias la prohibición de hacer castillos, fortalezas y casas fuertes según:

Ley $1^{a}$ tit. $18 p^{a} 1,18$ tit. 6 lib. 5 recop. que concuerda con el cap. 22 de los Corregidores que lo prohibe y la 1.8 tit. 5 lib. 6 recop. y alli Azmerdo desde el $n^{\circ}$ I y la 1.46 delbro. y en ella Antonio Gómez especialmente en el

36. Leopoldo Torres Balbás. Opus cit. "Cáceres y su Cerca Almohade". Págs. 138 y 139. Lo recoge del Archivo de la casa de López Montenegro, colec. de docs. $1^{\mathbf{a}}$ sign. prov., $\mathrm{n}^{\circ}$ 1-9, según cita Floriano en "La Villa de Cáceres y la Reina Católica I", reproduce el documento en las Págs. 55 y 56.

37. Leopoldo Torres Balbás. Opus cit. Págs. 139 a 142. 
$n^{\circ} 14$ Avilés Arendaño y otros que refiere Bobadilla en su política lib. 3 cap. $5 n^{\circ} 12^{38}$.

A estas leyes y ordenanzas, aún se remitían algunos escritos de finales del siglo XVII.

Si bien los Reyes Católicos, crearon la "Santa Hermandad" para castigo de delincuentes, otras medidas tomadas por los monarcas al inicio del último cuarto de siglo, lograron devolver el orden a la ciudad, a la vez que debilitar el poder de la nobleza. De gran efectividad fue el traer otros nobles a nuestra ciudad que, ocupando diversos cargos, desdibujaran la autoridad de la vieja estirpe sevillana. Estos son los casos de Don Pedro Enríquez, Adelantado de Andalucía, y de Alvaro de Portugal, el cual era hermano del Duque de Braganza, Alcaide de los Alcázares y Conde de Gelves cuya casa, con el tiempo, se emparentaría con la del Almirante Colón ${ }^{39}$.

La campaña de Granada comenzada en 1482, se caracteriza por el deseo de protagonismo de la nobleza sevillana. Entre los más destacados: el Marqués de Cádiz que obtuvo los títulos de Duque de Arcos y Marqués de Sáhara; el Duque de Medina Sidonia que, tras la toma de Granada consiguió Melilla ${ }^{40}$; el Adelantado de Andalucía Don Pedro Enríquez, casado con $D^{2}$ Catalina de Ribera que comenzó a levantar la Casa de Pilatos; el asistente D. Pedro de Pineda que, para ser rescatado de prisión en el desastre de la Ajarquía de Málaga, tuvo que vender su casa, que era medianera con el convento de las Dueñas. Dicha casa quedaría incorporada al mayorazgo de la Casa Ducal de Alba con el nombre de Palacio de las Dueñas y sería renovada en el XVI sin perder su carácter mudéjar.

Títulos como los de Conde de Ayamonte y Conde de Teba, en un miembro de la familia de los Guzmanes, se remontan a finales del siglo XV y comienzos del siguiente ${ }^{41}$.

\section{7.- LA NOBLEZA Y EL COMERCIO}

Tras la caída de Granada, la nobleza tiene que replantearse su razón de ser. Puede quedarse ociosa administrando sus amplios señoríos y si no quiere renunciar a las hazañas guerreras, tiene que marchar a Italia o a las Indias.

Son tiempos en que el poder de la nobleza tiene que compartirse con banqueros, mercaderes, comerciantes e incluso con clérigos que, con el aumento de los precios del trigo y otras especies, han visto revalorizados sus diezmos. Los cambios sociales influirán sobremanera en la arquitectura sevillana, pues

38. Juan Alonso de la Sierra Fernández. Las Torres, miradores de Cádiz. Pág. 141.

39. Joaquín Hazaña y La Rua. Opus cit. Pág. 160.

40. José $\mathbf{M}^{\mathrm{a}}$ de Mena. Opus cit. Pág. 149.

41. Antonio Collantes de Terán. Opus cit. Pág. 225. 
durante los próximos siglos XVI al XVIII, la arquitectura religiosa superará a la civil la cual había desbancado en suntuosidad y extensión a la clerical, durante los siglos XIII al XV.

Los nuevos planteamientos ecónomicos y el hecho de obtener la nobleza sus principales ingresos del campo, explotado por el sistema de arriendo a renta fija, hacen que ésta se empobrezca. Dicho hecho, junto a la inflación y depreciación de la moneda por la influencia de las riquezas que vienen de América, permiten que sólo conserven el patrimonio aquellos que pueden acceder a altos cargos, mientras que los demás han de buscar ocupación para no pasar apuros económicos ${ }^{42}$.

La compatibilidad entre nobleza y comercio muy normal en Cataluña y Cantabria, como igualmente había ocurrido en Flandes e Italia, no era nueva para Sevilla, por lo que a ella acuden los pilares más fuertes de su nobleza y de nuevo los Ponce de León, Guzmanes y Riberas serán rivales en el campo comercial:

\section{Al ser cosa que pende no de Leyes sino de estimación y costumbres ${ }^{43}$.}

La presencia de la nobleza en el comercio respondía más a una necesidad que a otros planteamientos locales. Se limitaba exclusivamente al comercio al por mayor y se realizaba a través de factores o apoderados. Empleando palabras de Alarcón en su comedia "El semejante a sí mismo":

\section{Es segunda maravilla un caballero de Sevilla sin rama de mercader.}

Ya desde la dominación árabe, el comercio, tanto en los puertos musulmanes como cristianos, se había visto enriquecido y reforzado con las comunicaciones marítimas italianas de Génova, Pisa y Venecia junto con Palermo, a fines del siglo XI, y con Florencia más tarde. Incluso en el siglo XII algunos reyes musulmanes mantenían tratados de comercio con Pisa y Génova ${ }^{44}$.

Compartían este esplendor los navíos que traían los tejidos de ciudades flamencas como Arras Iprés, Gante en Alemania y más tarde Brujas, poblaciones que hasta finales del XII y en el XIII, no alcanzarían la categoría de grandes urbes ${ }^{45}$.

Con el descubrimiento de América aumenta el prestigio comercial de Sevilla que llega a su zenit en el reinado de los Austrias. Capital universal del comercio, al ser el puerto más cómodo para el tráfico con Indias, llegó a denominarse por Mateo Alemán "Tierra de Jauja" y a convertirse en la ciudad más populosa de

42. Antonio Domínguez Ortiz. Opus cit. Págs. 85 y 86.

43. Norte de la Contratación de las Indias Occidentales. I. Pág. 118.

44. Vicente Lampérez y Romea. Opus cit. Tomo II. "Arquitectura Pública". Pág. 229.

45. Francisco Morales Padrón. Visión de Sevilla. Págs. 28 y 29. 
España, atrayendo a gran número de mercaderes que buscaban enriquecerse. Todo ello llevaría a una degradación de costumbres que la hizo acreedora de calificativos, a principios del XVI, como la "Nínive", "Babilonia Castellana", "Cairo Español" y "Chipre de los valientes".

Este comercio no era exclusivo con las Indias, Flandes o Florencia, sino que incluso llegaba a Cabo Verde. Múltiples extranjeros visitarían nuestra ciudad y al estarle por ley prohibido el comercio, casarían y quedarían para siempre en ella. De siempre los extranjeros, con la excepción de los portugueses, fueron bien acogidos en nuestra ciudad ${ }^{46}$.

\section{8.- SEVILLA BAJO LOS AUSTRIAS}

Ante los planteamientos ya expuestos, es de lógica suponer que muerta Isabel y reinando su hija Juana, esposa de Felipe de Austria, denominado "El Hermoso", de nuevo surjan los bandos de la nobleza. Desde la creación de la Inquisición el 11 de Febrero de 1481 por los Reyes Católicos, este escalón social había sido diezmado con condenas, a veces, sólo por el miedo al excesivo poder ${ }^{47}$.

Por ello, no es de extrañar que al querer apoderarse el Duque de Medina Sidonia de Gibraltar, le sea secuestrado el Condado de Niebla que es administrado por el arzobispo fray Diego de Deza, persona responsable de mantener a raya a la nobleza sevillana. No obstante, esta situación no es óbice para que el Rey, en 1508, sea aclamado por la ciudad a su llegada acompañado de la nueva Reina.

A la muerte del Rey Fernando en 1516, el cardenal Jiménez de Cisneros, en ausencia del príncipe Carlos, ocupa la regencia y Don Pedro de Girón, hijo del Conde de Ureña, junto con la Casa de Arcos ${ }^{48}$, se enfrenta a los derechos del Ducado de Medina Sidonia, obligando de nuevo a intervenir magistralmente al arzobispo fray Diego de Deza.

Tampoco afectaría a nuestra nobleza la revuelta "Comunera". Tan sólo unos pocos, reunidos en San Pablo al mando de Don Juan de Figueroa, sin conocimiento de su hermano Don Rodrigo de Ponce de León, Luis de Medina, los Perafanes, algunos Tellos y Don Juan de Guzmán caballero venticuatro, el cual había sido procurador de Sevilla en las cortes de La Coruña, deciden ocupar el alcázar con setecientos hombres y cuatro piezas de artillería. Tras despojar de su vara al alcalde de justicia, Jerónimo de Aguilas, prenden a su alcaide Don Juan de Portugal ${ }^{49}$. Sin embargo, al ver que el de Arcos, se pronunciaba contra el Rey, el de Medina Sidonia recupera el alcázar, recibiendo los Guzmanes, como

\footnotetext{
46. Antonio Domínguez Ortiz. Opus cit. Págs. 6, 76, 78 y 79.

47. José $M^{a}$ de Mena. Opus cit. Pág. 138.

48. Joaquín Hazañas y La Rua. Opus cit. Pág. 163.

49. Félix González de León. Opus cit. Noticias Históricas del origen de las calles... Pag. 51. Para Joaquín Hazañas, se trata de Jorge de Portugal. Opus cit. Pág. 165.
} 
premio de Carlos I, algunos señoríos agregados a la corona ${ }^{50}$. Gracias de nuevo al Arzobispo de Deza, al Asistente Alcaide del Alcázar y a Don Fernando Enríquez de Ribera que mantuvieron la calma, no llegó la situación a otros extremos.

Los enfrentamientos entre los de Arcos y los de Medina Sidonia, como en otros tiempos, iban acompañados con la toma de las puertas de la ciudad y de las torres de las iglesias que tenían asignadas; en ellas se fortificaban. En ocasiones, la importancia de la refriega obligó a intervenir al Arzobispo, asistentes y al resto de la nobleza ${ }^{5 !}$.

A pesar de que fueron obligados a abandonar la ciudad los mas significativos personajes y a prestar fidelidad jurada al monarca, en la plaza de San Francisco, de nuevo los alborotos llegan a la ciudad, esta vez de manos de la plebe con el denominado Motín de la Feria o del "Pendón Verde" 52.

La gran carestía de precios y el hambre producido como secuela de las Guerras Comuneras y de un periodo de malas cosechas, originó el 8 de mayo de 1521 una serie de incidentes en el "Mercado de la Feria". Sus gentes, al mando del carpintero Antón Sánchez, se apoderaron a la fuerza del estandarte verde, trofeo del reinado de Alfonso XI a los árabes, que permanecía guardado en la capilla de Jesús Nazareno o de los Cervantes en el hueco de la torre de Omnium Sanctorum. Con él, se dirigieron a la catedral, donde apedrearon las dependencias municipales y, aunque el Marqués de la Algaba con buen vino consiguió apaciguar los ánimos, sólo lograría aplacar el furor, pues los amotinados tras apoderarse de piezas de artillería del Palacio del Duque de Medina Sidonia, de nuevo volvieron a los enfrentamientos, por lo que el Asistente se vio obligado a acudir a las "grandes casas", que con palabras de Ortiz de Zúñiga:

Dioles la nobleza tal Santiago que los rompió con estragos en muertes y después en suplicios.

La nobleza demostraba, una vez más, en este primer tercio del siglo XVI, lealtad a la Corona $y$, salvo algún que otro incidente protagonizado por los Guzmanes en deseos de recuperar sus señoríos, fue fiel a ella ${ }^{53}$. Nada había que temer, en realidad la casa real poco oscurecía la nobleza sevillana, que según Lope llegaba a "oscurecer a la romana" ${ }^{54}$.

Era Sevilla en esta etapa el más preciado territorio nacional, ciudad:

Sin quien a España la grandeza falta, no pudiéndose llamar rey el que no es rey de Sevilla ${ }^{55}$.

50. José $\mathbf{M}^{\mathrm{a}}$ de Mena. Opus cit. Pág. 131.

51. Francisco Morales Padrón. La ciudad del Quinientos. Pág. 71.

52. Joaquín Hazañas y La Rua. Opus cit. Págs. 165 y 166.

53. Santiago Montoto. Sevilla en el Imperio. Pág. 152.

54. Santiago Montoto. Opus cit. Pág. 161.

55. Santiago Montoto. Opus cit. Pág. 211. 
Sin embargo este hecho no era nada nuevo, ni dependía del buen momento por el que se atravesaba. Abd al-Wāh-id-al Marrakusi, nos cuenta cómo nuestra ciudad, había impresionado a Yūsuf ibn Tāfusīn:

Antes de ver este país, yo creía que mi reino valía algo, ahora veo que estaba equivocado ${ }^{56}$... ningún lugar tiene temperatura más igual, aire más puro, mejores aguas, plantas más adoríferas, rocíos más abundantes, mañanas más gratas y tardes más suaves ${ }^{57}$.

En tan preciada ciudad, no resultaba extraño que la nobleza estuviera dominada más por el orgullo que por la grandeza, estando dispuesta a perder la fortuna con tal de no someterse a algo en desacuerdo con sus principios. El propio Duque de Arcos, antes de besar la mano del Rey, prefirió renunciar a sus rentas.

Grandes casas como la del Duque de Osuna, Alba, Béjar, Veragua. Marqueses como los de Ayamonte, Algaba, Fuentes y Valencina y condes como los de Cantillana, Olivares, Torrejón y Benajiar ${ }^{58}$, y un sin fín de títulos más, podrían engrosar la lista de la nobleza andaluza. La endogamia a veces dentro de un reducido estamento aún complicaba más la genealogía, sin que este hecho fuera óbice para que pudieran aparecer figuras nuevas ${ }^{59}$. Como dice Peraza, al hablar de donadíos:

No sólo se venden y no están en poder de sus propios señores, más de los linajes de muchos de aquellos a quién se hizo la merced ninguna memoria ni rastro queda en esta ciudad.

La nobleza sevillana, fiel sucesora de los doscientos caballeros que el Rey Sancho y su hijo Don Alfonso repartieron y enraizaron en Sevilla durante la decimotercera centuria, consiguió monopolizar e infiltrarse en los consejos."La Veinticuatría", si bien en un principio fue de carácter militar, en el XVI paś a desempeñar funciones de gobernación y administración de la ciudad. El número de sus miembros, en esta centuria, se elevaba a treinta y cinco, correspondiendo el nombramiento al rey; para desempeñar el puesto, había que ser además de noble, vecino de Sevilla ${ }^{60}$. El cabildo sería de los más aristocráticos de España; el jurado a pesar de que por su origen y misión debía representar al pueblo, exigía la condición de nobleza ${ }^{61}$.

56. E. Fagnan. Histoire des Almohades d'Abd El-Wad id Merrakechi. Pág. 118 de la traducción francesa referida a la Pág. 97 del texto árabe.

57. E. Fagnan. Opus cit. De la Pág. 138 de la traducción, la refiere de la Pág. 115 del original árabe.

58. Francisco Aguilar Piñal. Opus cit. Pág. 2.

59. Antonio Collantes de Terán. Opus cit. Pág. 230.

60. Santiago Montoto. Opus cit. Págs. 149-150.

61. Antonio Domínguez Ortiz. Opus cit. Pág. 85. 
La prosperidad sevillana, lograda durante el reinado de Felipe II y Felipe III, acabaría declinando en los primeros decenios del siglo XVII ${ }^{62}$. Buena parte de la "nobleza" dejó de ser "aristocracia", y aunque siguió usando blasones, perdió las virtudes o cualidades eminentes ${ }^{63}$.

Las epidemias y la escasez de cultivos, de nuevo originan desórdenes. El 19 de mayo de 1652, ante la falta de pan, en la calle Feria, eran atacados los panaderos de Alcalá de Guadaira y del Viso, subiendo la tensión en dias sucesivos. Precisamente el día 22 en los alrededores de Omnium Sanctorum,los alborotadores al mando de los tejedores Isidro de Torres y Francisco Hurtado, al grito de "Viva el Rey de España y muera el mal gobierno", acuerdan asaltar las casas nobles en busca de alimentos. Le toca primero el turno por proximidad, a la del Marqués de la Algaba, donde la nueva revuelta de la Feria establece su cuartel general y almacén de vituallas. La nobleza, en esta revuelta, no fue ultrajada, sólo desprovista de sus despensas ${ }^{64}$. Los ferianos habían nombrado capitán al hermano del Conde de Peñaflor, Juan de Villasís, caballero de la Orden de Calatrava, que aceptó de acuerdo con el poder y a fin de manejar más fácilmente esta revuelta que en ningún momento llegó a ofender a la realeza.

El 26 de septiembre de 1665 moría en Madrid Felipe IV, monarca que había debilitado enormemente el poder español. En los inicios de este reinado hacia 1640, de nuevo cobraba importancia el Ducado de Medina Sidonia por su parentesco con el Conde Duque de Olivares. Al estar casado el Duque de Braganza con Doña Luisa Pérez de Guzmán, hermana del de Medina Sidonia, con la sublevación de Portugal caía éste en desgracia junto con el reino de Sevilla y el Duque Don Alfonso, por quien se temía siguiera los mismos pasos. Tras su destierro a Toro, en 1642, donde fallece tres años después, Sevilla pierde un gran protector ${ }^{65}$ y el Ducado de Medina Sidonia, sus bienes y territorios de Sanlúcar de Barrameda ${ }^{66}$.

\section{9.-EL RENACER DE LA NOBLEZA SEVILLANA}

Los acontecimientos sucedidos durante el XVII no hacen mella en la oligarquía local que sigue detentando el poder durante el siglo XVIII. Los cargos continúan vinculados a las casas de mayor prestigio, por lo que a veces, éstos se convierten en defensores de sus propios intereses ${ }^{67}$, acaparando la nobleza el poder municipal, como ha seguido perdurando hasta nuestros días ${ }^{68}$. Durante este

62. Antonio Domínguez Ortiz. Opus cit. Pág. 131.

63. Francisco Armentia. En el diario ABC 1/8/86 Pág. 14 "El Generoso o aristócrata".

64. José $\mathbf{M}^{\mathbf{A}}$ de Mena. Opus cit. Pág. 163.

65. Joaquín Hazañas y La Rua. Opus cit. Págs. 178 y 179.

66. José $\mathbf{M}^{*}$ de Mena. Opus cit. Pág. 160.

67. Francisco Aguilar Piñal. Opus cit. Pág. 192.

68. Antonio Domínguez Ortiz y Francisco Aguilar Piñal. El Barroco y la Ilustración. Pág. 145. 
siglo, mantienen el dominio económico en base a unas ordenanzas que no se habían modificado desde $1527^{69}$, lo que ocasionaría una ciudad sin cambios radicales en su vida urbana. Dentro de las escasas alteraciones de la trama urbana, podemos reseñar el derribo del Arquillo y de la antigua Torre de San Miguel o del Almirantazgo (1726) que le dió el sobrenombre a la puerta más cercana de la catedral, de Puerta de la Torre. Con ella se demolían las casas contiguas, permitiéndose paso expedito hacia la Casa Lonja.

La pérdida del monopolio de Indias, la elevación de las rentas agrícolas y el traslado a Cádiz en 1717 de la Casa de la Contratación, llevaba a la clase dominante a nuevos planteamientos, sin embargo y a pesar de estas causas de decadencia sevillana, la nobleza renacería de su poderío dormido durante el XVII. Este nuevo resurgir lo comparte con el cabildo sevillano y así, a finales de este siglo, surge una arquitectura residencial más sofisticada, fruto de la desproporción existente entre las clases sociales. Frente a un $86 \%$ de jornaleros, sólo hay un $4 \%$ de propietarios o terratenientes ${ }^{70}$. Cada uno de ellos, en su barrio o plaza, son verdaderos reyes, uniéndose cada título a un emplazamiento.

El Duque de Alba, tras suceder en la posesión del Palacio de las Dueñas a los Pinedas, se establece por temporadas en esta zona de la población. El Duque de Veragua en la calle Borceguinería; El Duque de Arcos en la plaza de la Paja junto a los Terceros; el de Medina Sidonia en la plaza del Duque; el Duque de Medinaceli y Alcalá en la Casa de Pilatos; el Duque de Osuna en la calle Armas, cerca del convento de San Antonio; el de Sanlúcar, alguacil mayor de la Sta. Inquisición, junto a Sta. María la Blanca; el Duque de Alburquerque frente a San Andrés; el Marqués de Vallehermoso en Sta. Clara; los de Tablantes y Villarrubia en San Vicente; el de Torreblanca en Santiago; el de Moscoso en la de Correos o del Corso; el de Sortés en la de los Dados; el Marqués de Paradas en la de Gallegos, junto a San Juan de Dios; el de Grañina en la de Jesús; los Marqueses de la Algaba en la de Omnium Sanctorum; el de Ayamonte en la plaza de Regina; el de Montefuerte en la calle de Las Palmas; el de Villafranca y Carrión en Céspedes; el Conde de Ribera en la Gavidia; el de Remi en la calle Alcázares; el Conde de Mejorada en la calle Real; el de Santillana en la plaza de la Universidad; el de Benagiar en Monsalves; el Conde del Aguila, regidor de la ciudad y de personalidad muy acusada, en la plaza de los Trapos; el Conde de Cantillana en la plaza de la Universidad, delante de la Puerta de Jerez; El Conde de Castellar en Castellar; el Conde de Peñaflor en la plaza de Villasís; el Conde de Monteagudo en Sierpes ${ }^{71}$; el Conde de Monte Lirio en la plazuela del mismo nombre, etc.

69. Francisco Aguilar Piñal. Opus cit. Pág. 189.

70. Antonio Domínguez Ortiz. Sociedad Española. Pág. 259; R. Herr, trad. Elena Fernández Mel. España y la Revolución del Siglo XVIII. Pág. 78; Francisco Aguilar Piñal. Opus cit. Pág. 159.

71. Francisco Aguilar Piñal. Opus cit. Págs. 58 y 59. 
Según la Real Academia de la Historia, en 1759 el número de familias nobles avecindadas en Sevilla era de doscientas sesenta y cuatro, conservándose un manuscrito del Conde del Aguila en la Biblioteca Nacional, en el que figuran "Los títulos de Castilla existentes en Sevilla en 1770".

Los títulos nobiliarios avecindados, exceptuando los "Grandes" sumaban catorce condes y cuarenta y dos marqueses, recopilación que no parece exhaustiva ${ }^{72}$. Según Santiago Montoto ${ }^{73}$ pueden dividirse en Grandes como el Duque de Medina Sidonia, Arcos, Alcalá de los Gazules, etc. Señores de título como el Conde de Olivares, Marqués de Villanueva, Conde de Castellar, etc. Nobles que alcanzaron puestos de importancia en la Casa Real, en los consejos y tribunales, como el mariscal Diego Caballero, embajador Melchor Maldonado, y el virrey capitán general de Filipinas, primer presidente de la Audiencia, D. Francisco Tello de Guzmán, etc. Caballeros de las ordenes militares, como Zamudio de Alfaro, Francisco de Guzmán, etc. Caballeros veinticuatro y jurados, como Juan de Arguijo, Argote de Molina, Alcázar y Ortiz Melgarejo, a los que Peraza añade apellidos como los de: Guzmanes, Ponce de León, Monsalves, Cárdenas, Méndez, Castillos, Mendozas, Enríquez, Ribera, Saavedras, Tellos, Medinas, Ortices, Zúñigas, Sandovales, Torres, Gallegos, Roelas, Santillanes, Herreras, Pinedas, Moscosos, Esquiveles y Solises. Por último cabe reseñar caballeros pobres y simples hidalgos de entre los cuales, los hidalgos nuevos, por compra de hidalguía, fueron los peor considerados.

\section{0.- EL OCASO DE LA NOBLEZA SEVILLANA}

En el período que va de 1815 a 1819 , la lucha vuelve a la calle pero esta vez entre los partidarios del absolutismo y los progresistas, con resultado positivo para las comunidades religiosas que recuperan sus casas desamortizadas. Estos hechos suceden ante la indiferencia de un pueblo cansado de guerras y desórdenes. Un pueblo que tan pronto recibe entre silencio y berzas a Fernando VII, como tira de su carroza en 1823 con alegria jubilosa, todo ello a pocos meses de la explosión del Colegio de las Becas, sede de la Inquisición.

El neoclásico también nos deja, a comienzos del siglo XIX, bellas casas como el magnífico Palacio de los Condes de Casa Galindo en la plaza del Museo ${ }^{74}$; una muestra más de la arquitectura como exponente de la sociedad. No obstante, en este período continúa la degradación de la arquitectura noble, no sólo con derribos sino cambiando el uso de palacios, hospitales, colegios y conventos que son los más castigados; primero con la Guerra de la Independencia, posteriormente

72. Antonio Domínguez Ortiz y Francisco Aguilar Piñal. Opus cit. Pág. 167. Santiago Montoto. Opus cit. Pág. 160.

73. Santiago Montoto. Opus cit. Pág. 160.

74. Diego A. Cardoso Bueno. El distrito municipal I de Sevilla. Historia y Arte. Pág. 11. 
en 1838 con la exclaustración y por último con los sucesos de 1868 . Como resultado, la destrucción y el abandono se adueñan de muchos de estos edificios ${ }^{75}$. Como colofón a nuestro recorrido, señalamos que el periodista francés Luis de Teste, en 1872, contabilizaba cuarenta y tres marqueses, veintitrés condes y tres barones, destacando títulos como los de Duque de Montpensier -D. Antonio $\mathrm{M}^{\mathrm{a}}$ de Orleans y Borbón-, poderíos como el Duque de TSerclaes, el Conde de Castilleja de Guzmán, a quien le llamaban "pequeño rey" por la gran fortuna que llegó a poseer y el boato de su corte, así como el Marqués de Pickman que obtuvo su título el mismo año en que se fundaba la Fábrica de la Cartuja ${ }^{76}$, en una zona sólo apetecida por el barro alfarero de su suelo.

75. Diego A. Cardoso Bueno. Opus cit. Pág. 11.

76. Francisco Morales Padrón. Visión de Sevilla. Pág. 59. 

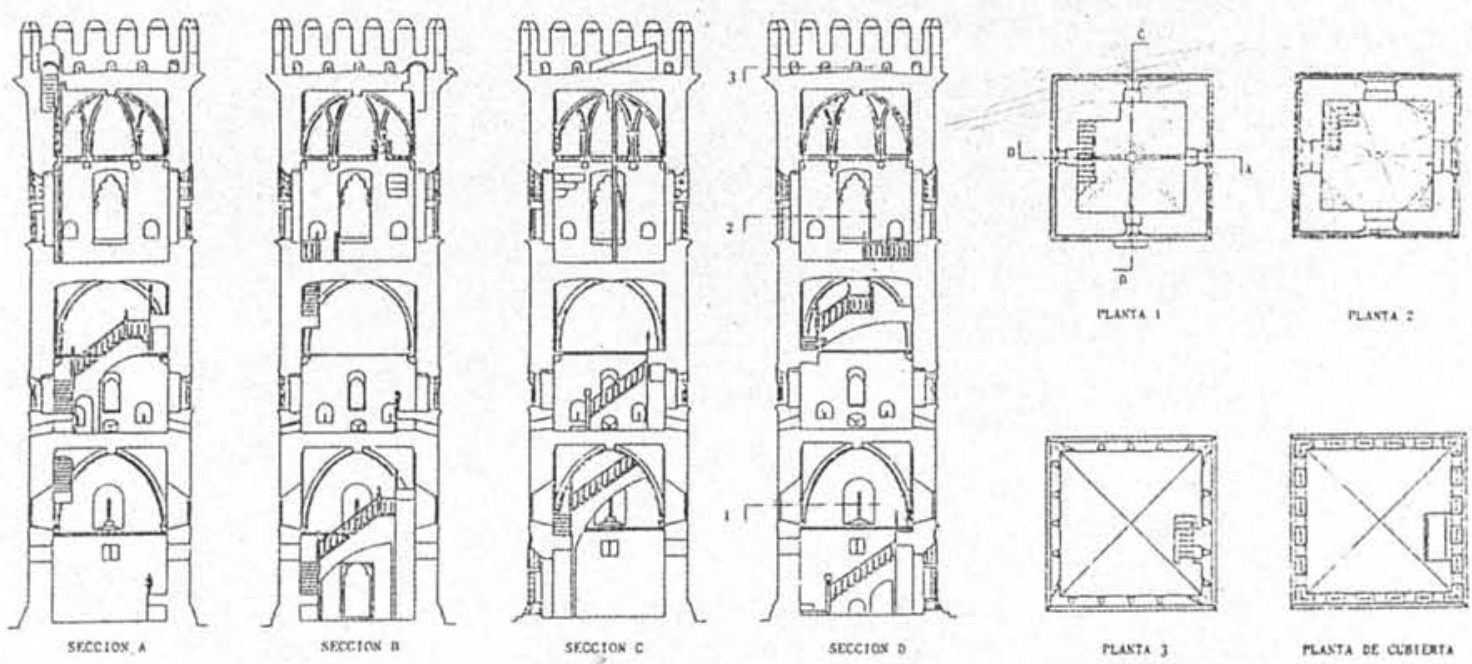
is B

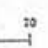

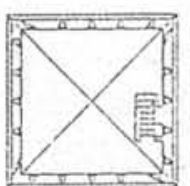

muxts 3

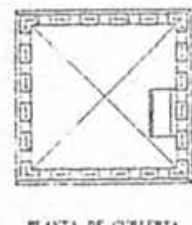

musta or castorts

Plantas y secciones de la torre de don fadrique en su estado actual 


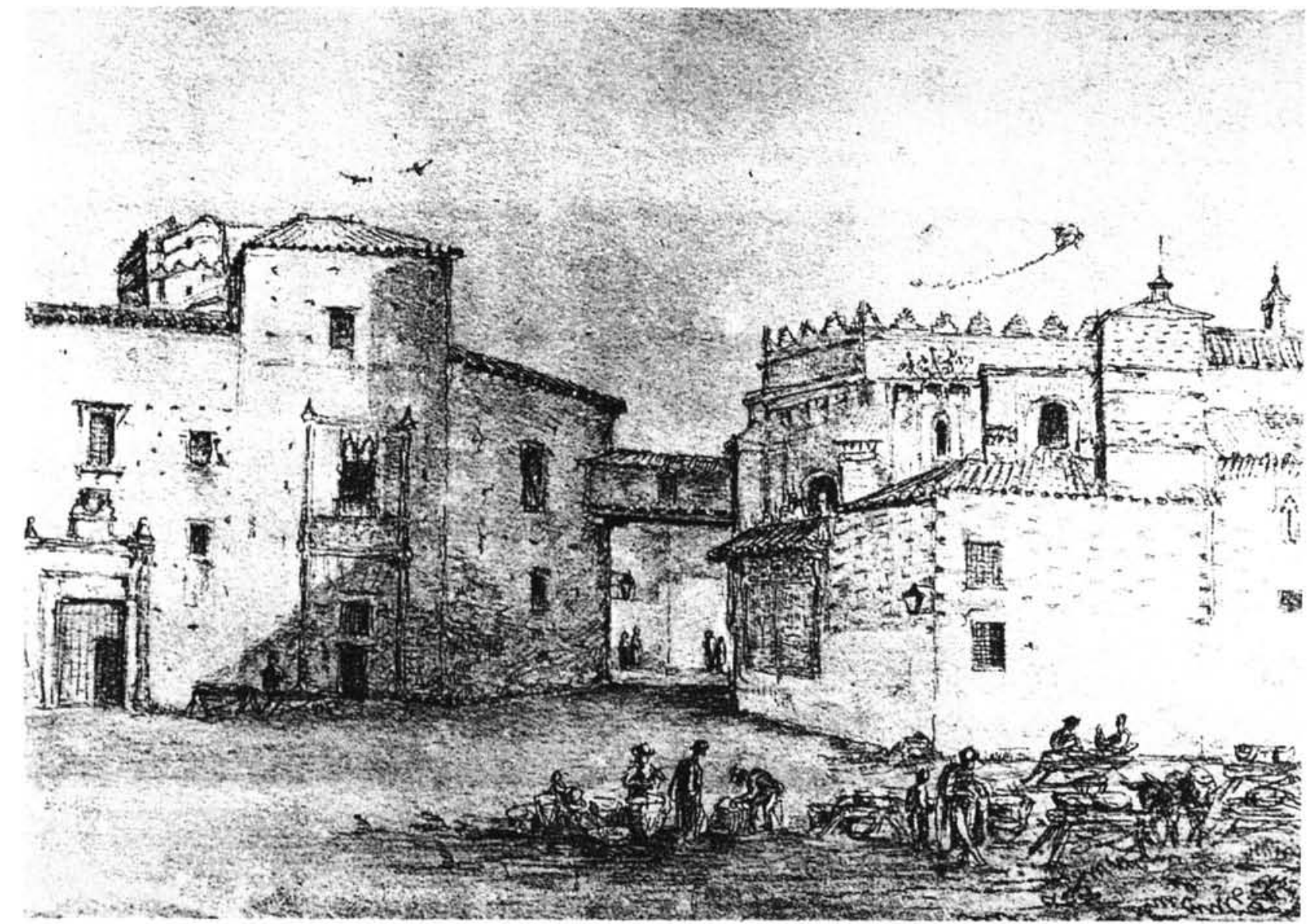

Dibujo de R. Ford de 1831 en el que aparece la casa palacio de los marqueses de la Algaba, con su torreón de puerta y el pasadizo de conexión con la iglesia de Omnium Sanctorum 


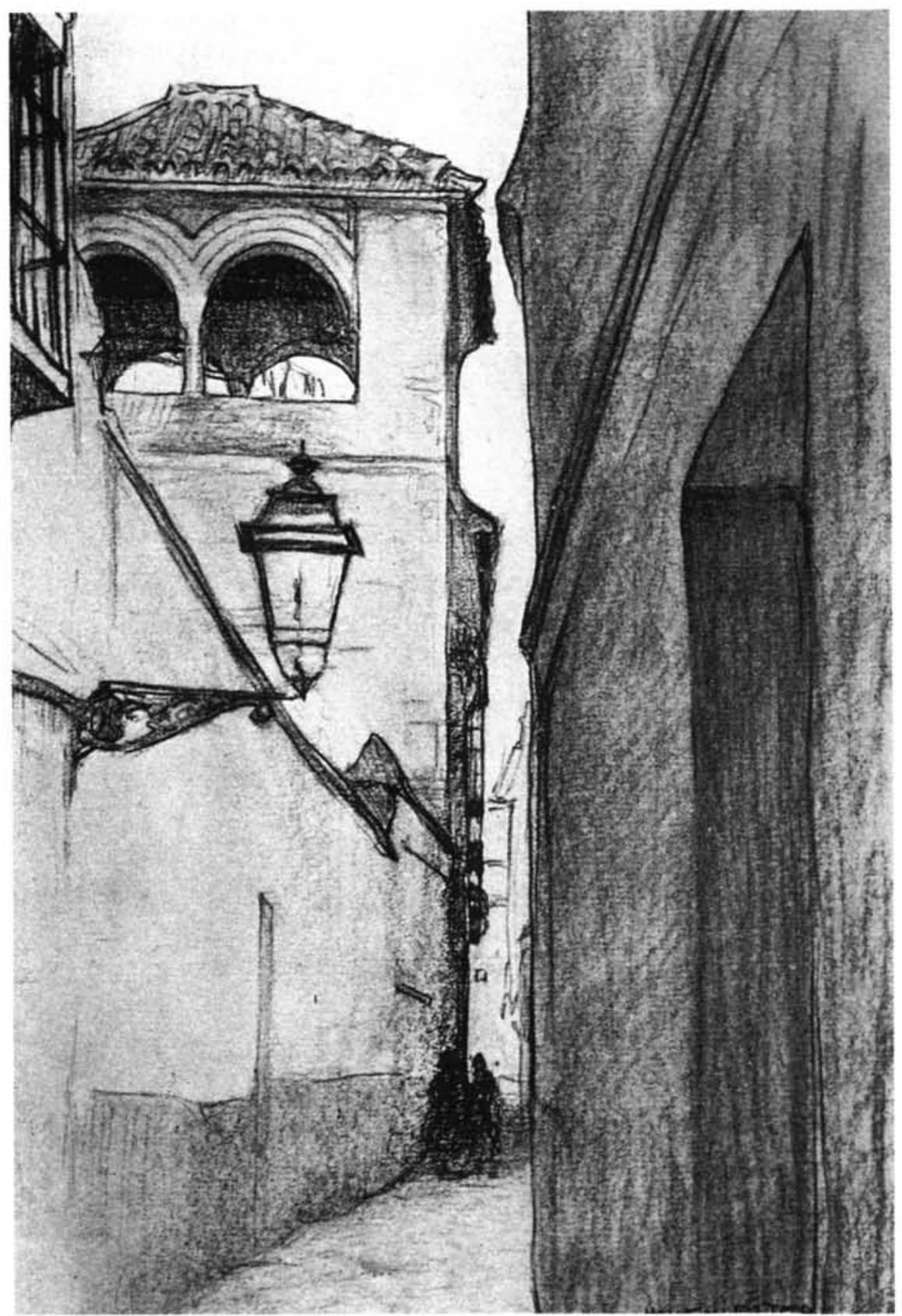

Torreón del palacio de Dos Hermanas del siglo XVII, aún se conserva asomándose a la estrechez de la calle Verde. 

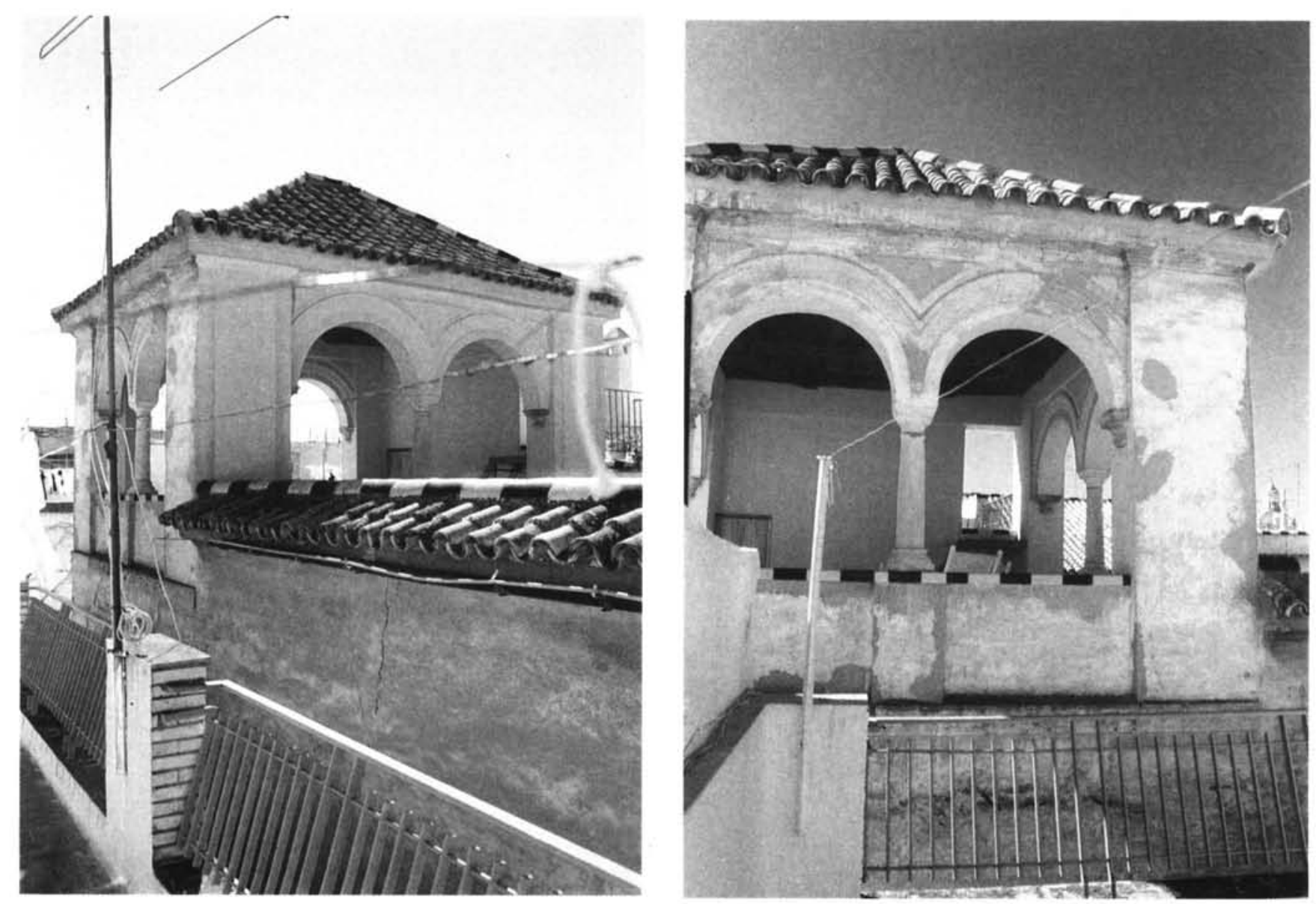

Estado actual del antiguo tirasol del palacio de Dos Hermanas. 


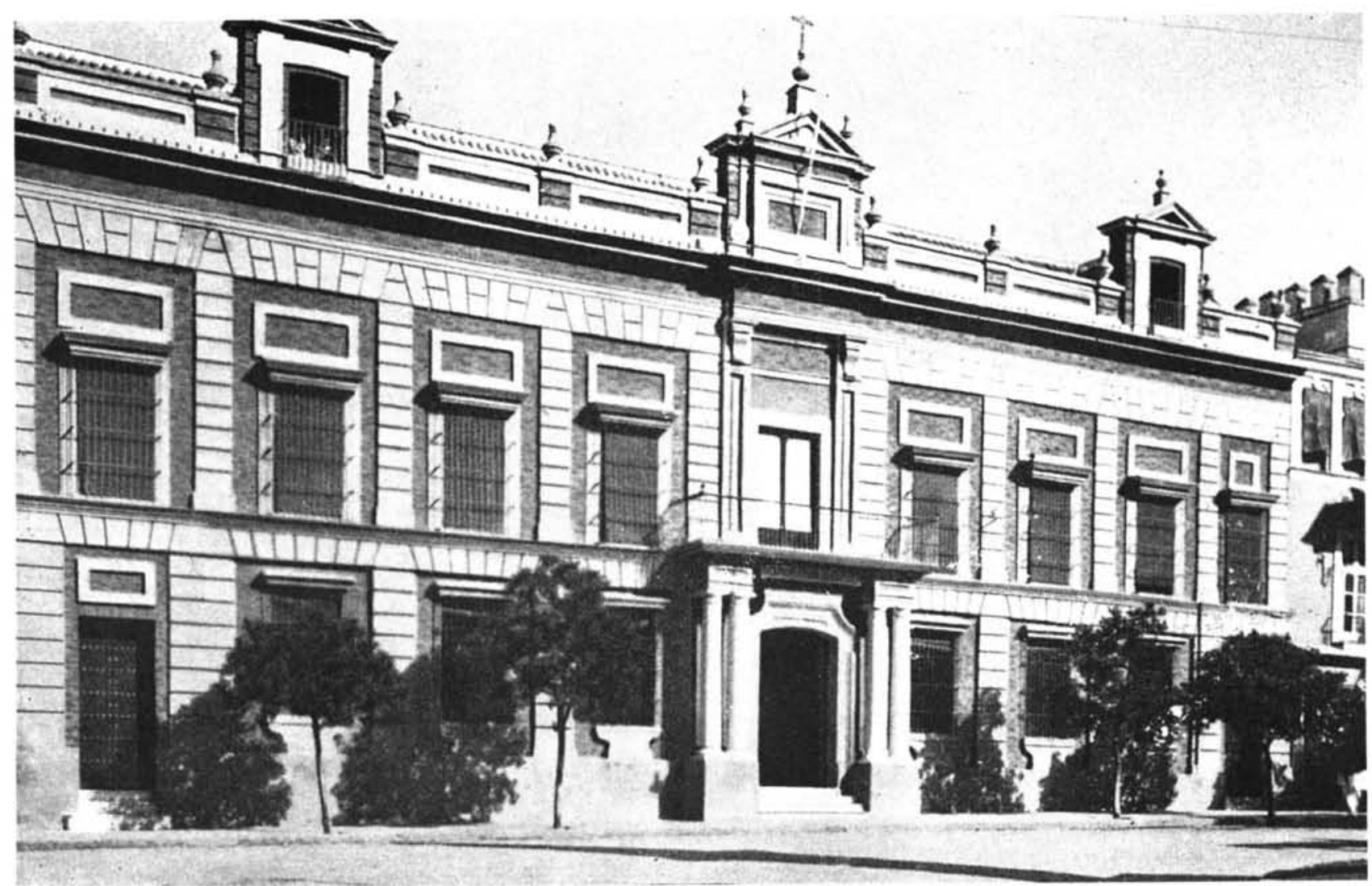




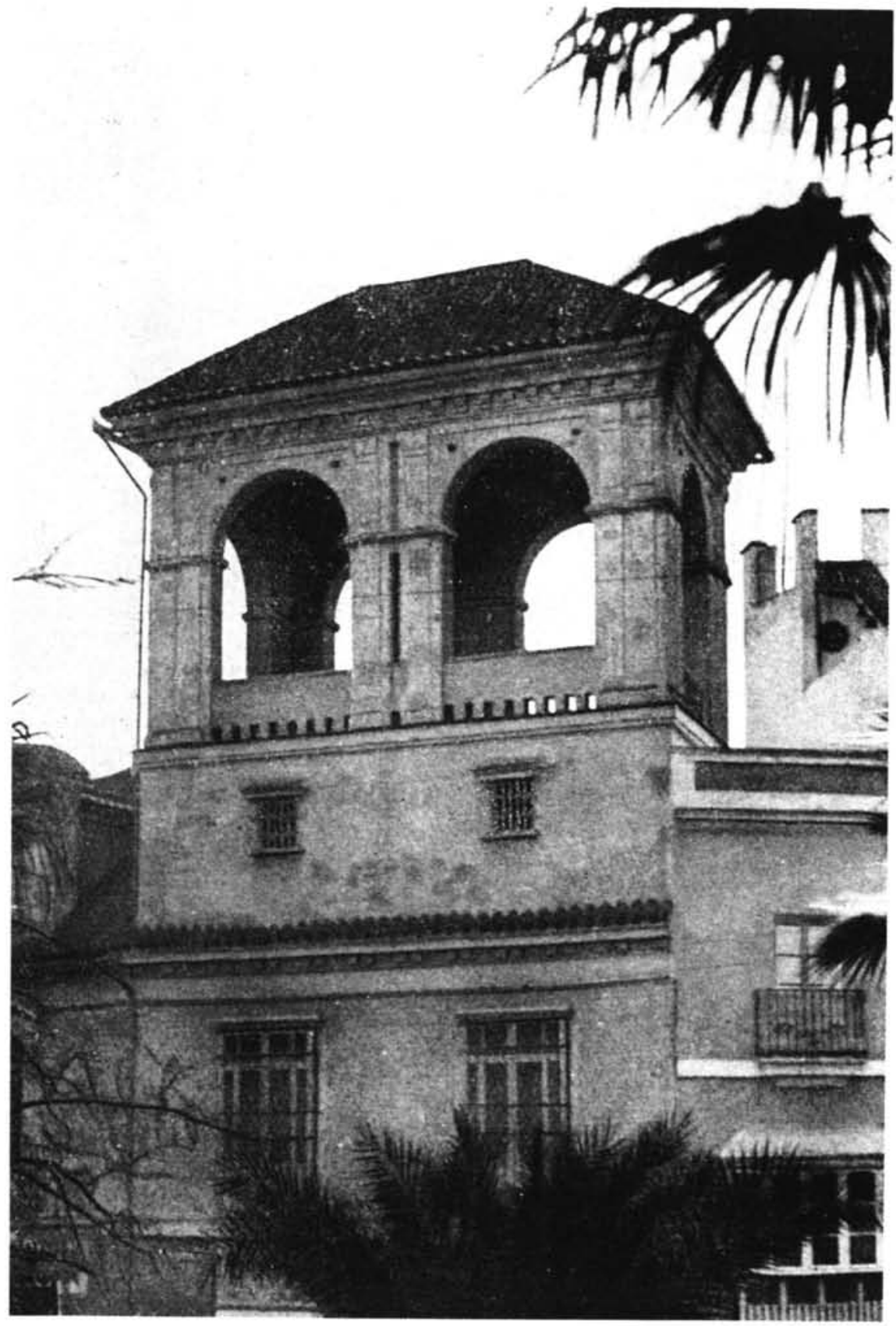

Algunos torreones como éste de la plaza del Cristo de Burgos, provienen de piezas labradas en el siglo XVII 


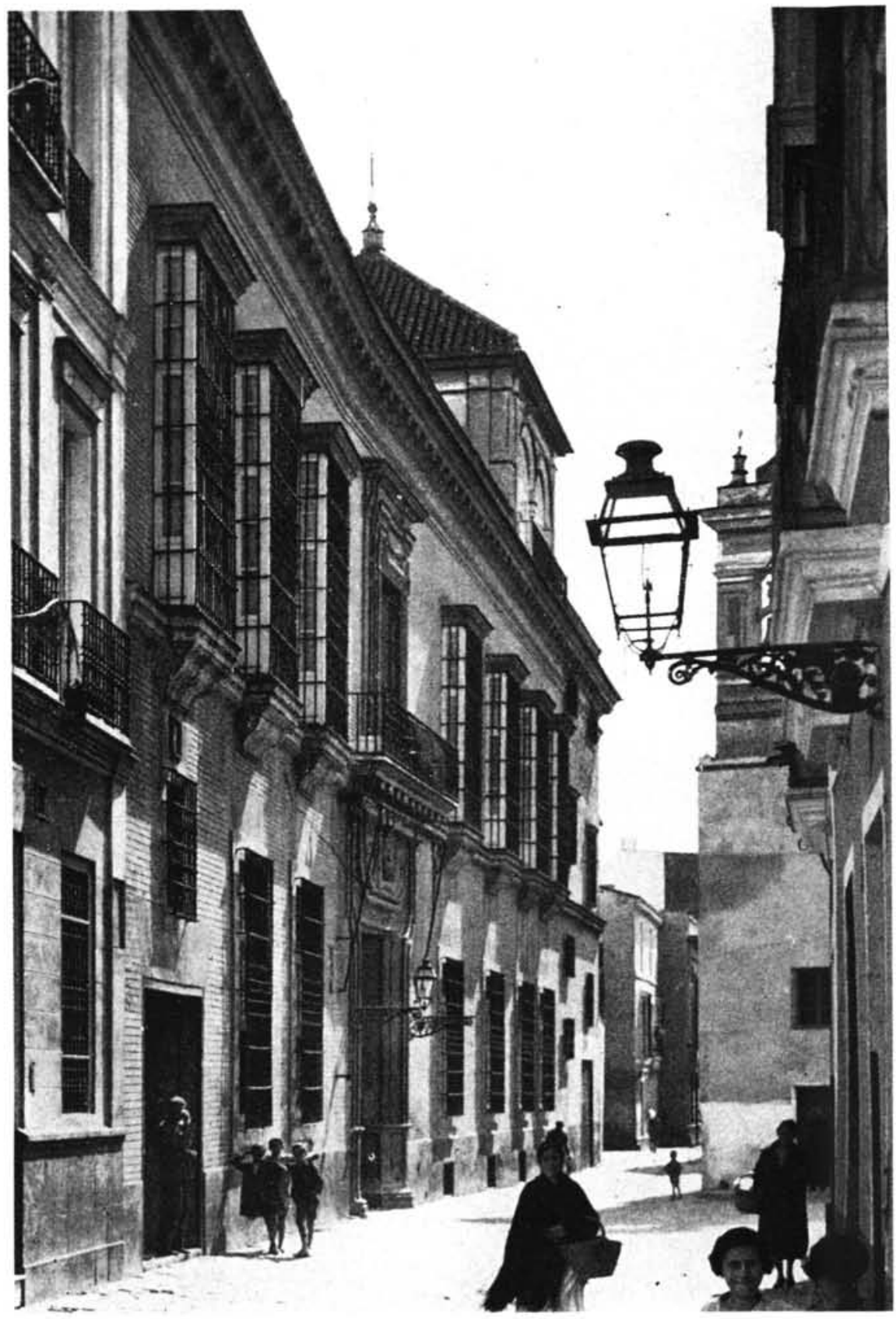

Torreón del XVIII de la antigua casa del almirante López Pintado, conocida como de los marqueses de Villapanés y Torreblanca del Aljarafe en el barrio de los Acipreses 


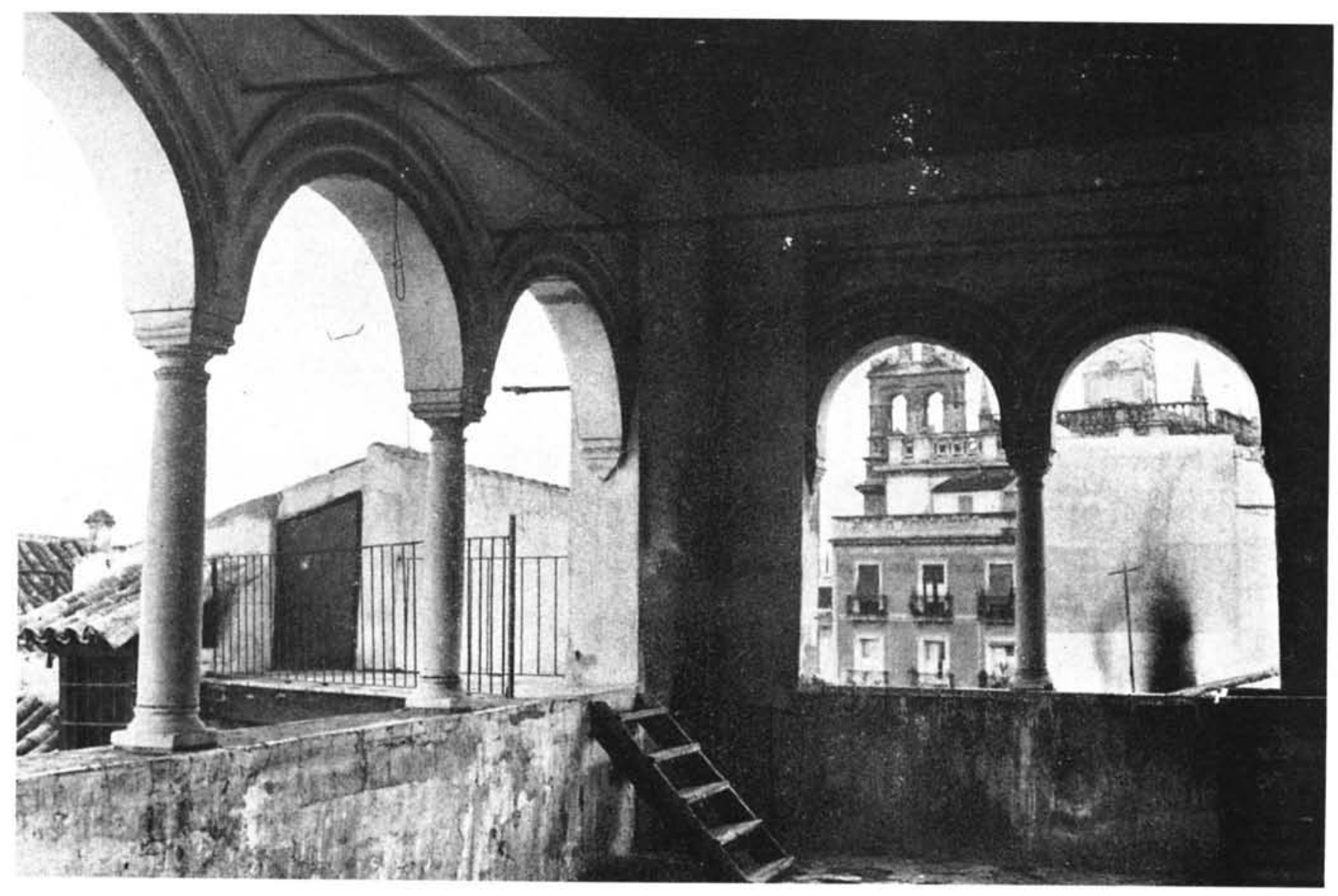

Torreón de la casa Luca de Tena que perteneció al conde del Aguila. 